\title{
The chemical and microphysical properties of secondary organic aerosols from Holm Oak emissions
}

\author{
N. Lang-Yona ${ }^{1}$, Y. Rudich ${ }^{1}$, Th. F. Mentel $^{2}$, A. Bohne ${ }^{2}$, A. Buchholz ${ }^{2}$, A. Kiendler-Scharr ${ }^{2}$, E. Kleist ${ }^{2}$, C. Spindler ${ }^{2}$, \\ R. Tillmann ${ }^{2}$, and J. Wildt ${ }^{2}$ \\ ${ }^{1}$ Department of Environmental Sciences, Weizmann Institute, Rehovot, 76100, Israel \\ ${ }^{2}$ Institut für Chemie und Dynamik der Geosphäre (ICG), Forschungszentrum Jülich GmbH, Jülich, Germany
}

Received: 30 January 2010 - Published in Atmos. Chem. Phys. Discuss.: 17 February 2010

Revised: 12 July 2010 - Accepted: 23 July 2010 - Published: 6 August 2010

\begin{abstract}
The Mediterranean region is expected to experience substantial climatic change in the next 50 years. But, possible effects of climate change on biogenic volatile organic compound (VOC) emissions as well as on the formation of secondary organic aerosols (SOA) produced from these VOC are yet unexplored. To address such issues, the effects of temperature on the VOC emissions of Mediterranean Holm Oak and small Mediterranean stand of Wild Pistacio, Aleppo Pine, and Palestine Oak have been studied in the Jülich plant aerosol atmosphere chamber. For Holm Oak the optical and microphysical properties of the resulting SOA were investigated.

Monoterpenes dominated the VOC emissions from Holm Oak (97.5\%) and Mediterranean stand (97\%). Higher temperatures enhanced the overall VOC emission but with different ratios of the emitted species. The amount of SOA increased linearly with the emission strength with a fractional mass yield of $6.0 \pm 0.6 \%$, independent of the detailed emission pattern. The investigated particles were highly scattering with no absorption abilities. Their average hygroscopic growth factor of $1.13 \pm 0.03$ at $90 \% \mathrm{RH}$ with a critical diameter of droplet activation was $100 \pm 4 \mathrm{~nm}$ at a supersaturation of $0.4 \%$. All microphysical properties did not depend on the detailed emission pattern, in accordance with an invariant $\mathrm{O} / \mathrm{C}$ ratio $(0.57(+0.03 /-0.1))$ of the SOA observed by high resolution aerosol mass spectrometry.
\end{abstract}

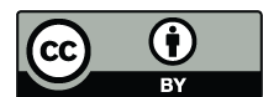

Correspondence to: Th. F. Mentel (t.mentel@fz-juelich.de)
The increase of Holm oak emissions with temperature $(\approx 20 \%$ per degree) was stronger than e.g. for Boreal tree species $(\approx 10 \%$ per degree). The SOA yield for Mediterranean trees determined here is similar as for Boreal trees. Increasing mean temperature in Mediterranean areas could thus have a stronger impact on BVOC emissions and SOA formation than in areas with Boreal forests.

\section{Introduction}

Earth's climate is affected by aerosols both directly and indirectly. The direct effect of aerosols on climate is due to scattering and/or absorbing incoming solar and outgoing terrestrial radiation (Pilinis et al., 1995; Chen et al., 2009; Kaufman et al., 2002). Aerosols serving as cloud condensation nuclei $(\mathrm{CCN})$ indirectly affect climate and precipitation by modifying the microphysical properties of clouds and cloud coverage (Albrecht, 1989; Twomey, 1977; Kaufman and Koren, 2006; Kaufman et al., 2005; Kaufman et al., 2002; Lohmann and Feichter, 2005). Although very important, there are significant uncertainties regarding aerosols' contribution to Earth's radiation balance and climatic changes (Solomon et al., 2007).

Secondary organic aerosols (SOA) are formed in the atmosphere via the (multiple) oxidation of volatile organic compounds (VOC) by reactive species such as ozone, hydroxyl radical and the $\mathrm{NO}_{3}$ radical (Hallquist et al., 2009; Monks et al., 2009). Globally, emissions from vegetation are the dominant source of VOC (Guenther et al., 1995). Hence biogenic SOA formation contributes to number (Kulmala et al.,

Published by Copernicus Publications on behalf of the European Geosciences Union. 
2004a) and mass load of atmospheric aerosols and modifies climate relevant properties like water-solubility, droplet activation, and indices of refraction. Although vegetation has a significant influence on SOA composition in the atmosphere, there is an ambiguity regarding possible influences on climate and vice versa. For example, plants exposed to high pollution and $\mathrm{CO}_{2}$ levels will close their stomata leading to reduced ozone and $\mathrm{CO}_{2}$ uptake and hence higher ozone levels at the surface (Sitch et al., 2007). Heat and drought will have similar effects (Mercado et al., 2009), while also affecting the amount and composition of emitted VOC. Due to slow adaptation rates of trees and other long lived vegetation, climatic changes accompanied by droughts, heat waves, and high pollution may put vegetation under stress conditions which may consequently alter VOC emissions and possibly change the formed SOA mass and properties in the atmosphere. In turn, SOA formed from emitted VOC may influence climate through the direct and the indirect effects and by changing diffuse versus direct radiation (Kulmala et al., 2004b; Barth et al., 2005).

The uncertain coupling between climate change and vegetation requires a thorough investigation in order to estimate its contribution to Earth's energy balance. With the Jülich plant aerosol atmosphere chamber (JPAC) we set up a tool to study photochemical processes of SOA formation from real plant emissions and to characterize the climate-relevant properties. In previous studies species from Boreal and temperate Midlatitude forests were investigated (Mentel et al., 2009; Kiendler-Scharr et al., 2009a; Kiendler-Scharr et al., 2009b; Hao et al., 2009), here we will focus on Holm Oak (Quercus ilex $\mathrm{L}$.), an evergreen species of another sensitive eco-system, the Mediterranean forest. This species is a strong emitter of monoterpenes (Kesselmeier et al., 1996; Staudt et al., 1993) and ozonolysis of Holm Oak emissions leads to SOA formation (Van Reken et al., 2005).

The Mediterranean forest is characterized by dry summers and mild, rainy winters. It is common in five Mediterranean climate zones, on the west coast of continents in the mid-latitudes: the Mediterranean Basin, California, Central Chile, Southwest Australia, and the Western Cape in South Africa. Recent model studies suggest that future climate will be characterized by high temperatures, extended drought periods, as well as heat and heavy photochemical smog episodes (Solomon et al., 2007). In that case Mediterranean species will be exposed to stress conditions, which will change their VOC emission strengths and pattern (Staudt and Bertin, 1998).

In our experiment we investigated the effects of high temperature and light intensity on the Holm Oak's VOC emissions, on the SOA formed from their oxidation by $\mathrm{OH}$ and ozone, as well as on the SOA chemical composition and microphysical properties. Holm Oak (Quercus ilex L.) was chosen as a model plant for the Mediterranean area. It is a common Mediterranean species and its VOC emissions have been extensively studied (Bertin et al., 1997; Staudt and Bertin,
1998; Kesselmeier et al., 1996; Seufert et al., 1997; Staudt et al., 2002). Holm Oak monoterpene emissions depend on temperature and on photosynthetic photon flux density (PPFD) (Staudt and Seufert, 1995; Staudt and Bertin, 1998). Ocimene emissions from this species have a very high temperature dependence compared to other monoterpene emissions (Staudt and Bertin, 1998). We varied the temperature in the plant chamber from experiment to experiment while holding constant the conditions in the reaction chamber. This allowed for changing the emission strengths and the emission pattern of the VOC introduced into the reaction chamber and to determine the dependence of SOA formation on these changes.

\section{Methods}

Experiments were carried out in the plant aerosol atmosphere chamber facility (JPAC) at Forschungszentrum Jülich, Germany, which was previously described in detail by Mentel et al. (2009). A simplified illustration of the setup is shown in Fig. 1. In short, it consists of three Borosilicate glass chambers with Teflon floors. Each chamber is mounted in a separate climate-controlled housing and operated as continuously stirred tank reactor with Teflon fans providing homogeneous mixing. During the experiments described here the smallest chamber $(164 \mathrm{~L}$ ) was used as plant chamber (see Fig. 1a). This chamber contained a Holm Oak (Quercus ilex L.) originating from Italy, and grown in Jülich, Germany. As a low reference case we kept a small stand of Mediterranean trees composed of 3 Wild pistacio (Pistacia palaestina L.), 3 Aleppo Pine (Pinus halepensis L.) and one Palestine Oak (Quercus calliprinos L.) in the second plant chamber $(1150 \mathrm{~L})$. The trees were brought from the Judean Mountains, Israel.

The residence times of the purified and humidified air in the plant chambers were 5 to $20 \mathrm{~min}$. At the inlet of the plant chamber VOC impurities were reduced to $<1$ part per trillion (ppt) by a palladium catalyst at $450{ }^{\circ} \mathrm{C}$. $\mathrm{NO}_{\mathrm{x}}$ concentrations were below $100 \mathrm{ppt}$ and $\mathrm{O}_{3}$ concentrations were below 1 parts per billion (ppb). The air from the plant chambers containing the plant emitted VOC was transferred to the $1450 \mathrm{~L}$ reaction chamber (see Fig. 1b). There the average residence time was $65 \mathrm{~min}$.

Constant conditions in the plant chamber included $\mathrm{CO}_{2}$ concentration of 350 parts per million (ppm) and a maximum dew point of $12{ }^{\circ} \mathrm{C}$ during periods of illumination. The solar light spectrum was simulated by discharge lamps (HQI 400 W/D; Osram, Munich, Germany), reaching PPFD of up to $800 \mu \mathrm{mol} \mathrm{m}{ }^{-2} \mathrm{~s}^{-1}$ at full illumination and at typical midcanopy heights. This intensity is equivalent to about a third of the high intensities often found in Mediterranean areas (e.g. Manes et al., 1997). Infrared radiation (between 750 and $1050 \mathrm{~nm}$ ) was blocked by filters (type IR3; Prinz Optics, 
Stromberg, Germany). The shortest wavelength was about $350 \mathrm{~nm}$ due to the absorption of UV light by the glass walls.

The plants were kept in a growth room before they were used in the experiments (PPFD $\approx 350-500 \mu \mathrm{mol} \mathrm{m}^{-2} \mathrm{~s}^{-1}$, $T \approx 25^{\circ} \mathrm{C}$ during daytime $(12 \mathrm{~h})$ and $0 \mu \mathrm{mol} \mathrm{m}^{-2} \mathrm{~s}^{-1}$ $T \approx 22^{\circ} \mathrm{C}$ during nighttime ( $12 \mathrm{~h}$ ). They were given two days to adapt to the conditions in the plant chambers. Note that Quercus ilex and the Mediterranean stand were housed in two separate chambers. The chamber containing Quercus ilex was operated at PPFD $\approx 800 \mu \mathrm{mol} \mathrm{m}^{-2} \mathrm{~s}^{-1}$, the chamber containing the stand was operated at PPFD $\approx 480 \mu \mathrm{mol} \mathrm{m}^{-2} \mathrm{~s}^{-1}$. Thus the setup could be switched within one day without perturbing the plants.

The emission strength and the emission patterns of the VOC were modified by varying the temperature in the plant chamber between $20^{\circ} \mathrm{C}$ and $35^{\circ} \mathrm{C}$. The temperature was changed in the morning before the experiment, so the plant had $7-8 \mathrm{~h}$ time to adjust to the new temperature under visible light.

VOC flow exiting the plant chamber was directed into the reaction chamber, and a small portion was directed into a GC-MS system for VOC speciation and quantification (Heiden et al., 1999). A second GC-MS at the outlet of the reaction chamber was used for measuring deuterated cyclohexane and less reactive monoterpenes as tracers for calculating the $\mathrm{OH}$ concentrations (Kiendler-Scharr et al., 2009a).

In addition to the VOC from the plant chamber, ozone and water vapor containing air was introduced to the reaction chamber. By regulating the water vapor concentration, the PPFD-dependent transpiration of the plants was compensated and the relative humidity (RH) was kept constant at around $65 \%$. OH radicals in the reaction chamber were generated by ozone photolysis (Philips, TUV 40W, $\lambda_{\max }=254 \mathrm{~nm}$ ) followed by the reaction of $\mathrm{O}^{1} \mathrm{D}$ with water vapor.

To optimize the particle growth to diameters of $>150 \mathrm{~nm}$ for the optical measurements, two types of experiments were performed with the Holm Oak. In one, the lights in the plant chamber were turned on in the morning but there was no UV light in the reaction chamber. The VOC reacted with ozone forming only a few hundreds of particles. Five hours later UV lights were switched on, when the reaction chamber was in steady state regarding ozonolysis products and VOC that have not reacted with ozone. Then between $10^{4}$ and $10^{5}$ particles per $\mathrm{cm}^{3}$ were formed by $\mathrm{OH}$ reactions of unreacted VOC and of ozonolysis products (compare Mentel et al., 2009). SOA formation was induced by increasing the oxidant levels and this type of experiments will be called $O x$.-induced. In the second type of experiments, the reaction chamber UV lights were initially turned on while the plant chamber was kept dark. Thus, when the lights in the plant chamber were switched on, $\mathrm{OH}$ radicals were already present in the reaction chamber and SOA formation was induced by $\mathrm{OH}$ and ozone reactions after reaching the threshold concentration of VOC necessary for SOA formation. We will call this type of experiments VOC-induced. (The VOCinduced experiments allowed for large VOC inputs in the reaction chamber without uncontrolled nucleation of particles by pure ozonolysis.) In addition we used the Mediterranean stand as low emission reference in five Ox.-induced experiments.

During the $O x$.-induced experiments Ozone levels were about 90 ppb without UV light, and they dropped to about 50-60 ppb when the UV light was turned on. In the $V O C$-induced experiments ozone concentrations were about $80 \mathrm{ppb}$ with the UV light on and they dropped by up to $35 \mathrm{ppb}$ when the plants started to emit.

A Condensation Particle Counter (CPC, TSI3022A) with a nominal activation diameter of $7 \mathrm{~nm}$ was directly connected to the reaction chamber, counting the total number of particles formed in the chamber. A stainless steel tube directed the SOA to a line of analytical equipment used to characterize the chemical and microphysical properties of the aerosols: aerosol mass spectrometry, hygroscopicity, activation diameter and optical properties (see Fig. 1c-f). This line was pumped with a total flow of $12-13 \mathrm{~L} \mathrm{~min}^{-1}$. A scanning mobility particle sizer (SMPS, TSI3071+TSI3025A) measured the number size distribution between 10 and $500 \mathrm{~nm}$. The obtained size distributions were used to determine particle growth rates and were converted into volume distributions to determine particle volume yields.

A High-Resolution Time-of-Flight Aerosol Mass Spectrometer (HR-ToF-AMS, Aerodyne Research Inc., DeCarlo et al., 2006) was used to measure the chemical composition of the SOA (see Fig. 1c). The particles enter the instrument through an aerodynamic lens that enhances the particle concentration with respect to gas phase by about $10^{7}$ so that only particle composition is detected, except for the main components of the air, $\mathrm{N}_{2}, \mathrm{O}_{2}, \mathrm{CO}_{2}$, and $\mathrm{H}_{2} \mathrm{O}$ vapor. A tungsten oven at $600^{\circ} \mathrm{C}$ flash-vaporizes the particles under vacuum. No refractory materials are produced in the reaction chamber and by comparison to size distribution measurements collection efficiencies of $100 \%$ were found (Kiendler-Scharr et al., 2009b). The vapors are ionized by $70 \mathrm{eV}$ electron impact (EI), and the resulting ions are detected by means of a timeof-flight mass spectrometer applying either a high-sensitivity mode (V-mode) or a high-resolution mode (W-mode). In the MS mode, ion signals are integrated over all particle sizes, thus the overall composition of the SOA is determined. In addition, in the pToF-mode a size resolved chemical composition is measured in V-mode configuration by means of a chopper-triggered particle-time-of-flight distance (DeCarlo et al., 2006).

The EI technique causes substantial fragmentation of the molecules. Here we applied elemental analysis to the highresolution mass spectra to calculate the oxygen to carbon ratio $(\mathrm{O} / \mathrm{C})$ and to infer changes in the oxidation state of the particles (Aiken et al., 2007, 2008). Shortly, the ion signals are fitted with a peak shape function considering deviations from an ideal Gaussian peak shape, which is empirically 


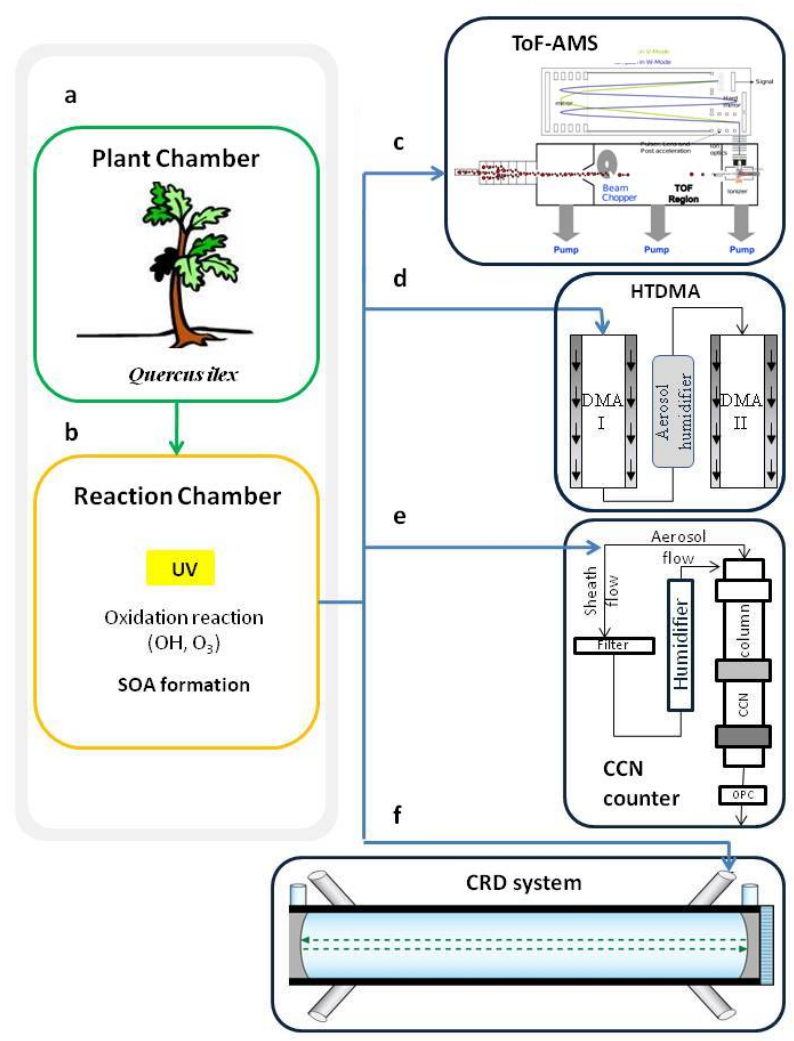

Fig. 1. Illustration of the experimental setup including the plant chamber (a). The volatile organic compounds (VOC) flow is directed into the reaction chamber (b), in which the oxidation processes occur. The formed secondary organic aerosols (SOA) flow is directed into the different instruments: High Resolution Time-ofFlight Aerosol Mass Spectrometer (AMS, c); hygroscopic tandem differential mobility analyzer (HTDMA, d); cloud condensation nuclei $(\mathrm{CCN})$ counter $(\mathbf{e})$; and continuous wave cavity ring down $(\mathrm{CW}$ CRD) system (f).

determined from an average of ion signals (DeCarlo et al., 2006). The calculation of $\mathrm{O} / \mathrm{C}$ is performed by counting the signals of all ions in the mass spectrum and summing up the number of oxygen and carbon atoms in the respective ions. The number of oxygen and carbon atoms in each ion signal is inferred from the heavy atom mass defect, which is resolved for $\mathrm{C}_{\mathrm{x}} \mathrm{H}_{\mathrm{y}} \mathrm{O}_{\mathrm{z}}$-fragments in the $\mathrm{W}$-mode.

Corrections to remove the influence of gaseous components must precede the calculation of the $\mathrm{O} / \mathrm{C}$ ratio. Plant chamber air contains $\mathrm{CO}_{2}$ and water vapor and both gas phase species contribute to the mass spectra. The contribution of gas-phase $\mathrm{CO}_{2}$ to $\mathrm{m} / \mathrm{z}, 44$ and water vapor at $\mathrm{m} / \mathrm{z}$ 18 was inferred from measurements when no particles are present and subtracted to obtain the particle signals which were used in the elemental analysis (Allan et al., 2004). A significant contribution to organic mass is located at $\mathrm{m} / \mathrm{z} 28$ $\left(\mathrm{CO}^{+}\right)$and is thus important for the $\mathrm{O} / \mathrm{C}$ ratio. The signal of $m / z, 28$ arising from particles was separated from the very large signal of gas phase $\mathrm{N}_{2}^{+}$by making use of the fact that in the pToF-mode gaseous components appear at much shorter time-of-flight than particle components (Liu et al., 1995). We determined the ratio $\mathrm{m} / \mathrm{z} 28$ and $\mathrm{m} / \mathrm{z} 44$ for the particulate phase in the pToF-data and obtained a fixed ratio of about $1 \pm 0.2$ over the whole campaign (compare Kiendler-Scharr et al., 2009b). Therefore we assumed that also in the MS mode organic $\mathrm{m} / \mathrm{z} 28$ equals organic $\mathrm{m} / \mathrm{z} 44$.

There is also a possibility of residual liquid water in the particles besides water from the fragmentation of organic compounds, since the experiments were performed at $65 \% \mathrm{RH}$. Because of the low hygroscopicity of the particles, it was assumed that all $\mathrm{m} / \mathrm{z} 18$ signals arise from organics leading to a ratio of particulate water (at $\mathrm{m} / \mathrm{z}, 18$ ) to particulate organics (at $\mathrm{m} / z$ 44) of 1.7. This is the upper limit for the organic contribution at $m / z$ 18. Since increasing the $\mathrm{H}_{2} \mathrm{O}^{+}$ signal in the mass spectra adds oxygen without adding carbon, the obtained $\mathrm{O} / \mathrm{C}$ ratio is also an upper limit. Hygroscopic growth observed at $\mathrm{RH}=65 \%$ is below $5 \%$ in diameter (see below). Assuming this water volume fraction, the $\mathrm{O} / \mathrm{C}$ ratio would be lowered by $15 \%$.

For the microphysical measurements, the aerosol was dried with silica gel diffusion driers achieving relative humidities of about $3 \%$ and then neutralized with $\mathrm{Kr}-85$ neutralizers (TSI 3077).

The hygroscopic growth was measured by a home built hygroscopic tandem differential mobility analyzer (HTDMA, Buchholz, 2007, see Fig. 1d). The dried aerosol was size-selected with a differential mobility analyzer (DMA, TSI3071) and humidified in a controlled manner. The size of the humidified aerosol was determined with an SMPS (TSI3071+TSI3022A) operating at the same RH. The particles remained for approximately $20 \mathrm{~s}$ in contact with the selected humidity before they enter the SMPS which operated with sheath air of the same humidity. The hygroscopic growth factor (GF) is defined as the ratio of wet particle diameter $\left(D_{\text {wet }}\right)$ and the original diameter of the particle $\left(D_{\text {dry }}\right)$. For two selected sizes (150 and $250 \mathrm{~nm}$ ) GF were determined between 3 and $98 \%$ RH.

Cloud droplet activation was studied using a commercial cloud condensation nuclei $(\mathrm{CCN})$ counter $(\mathrm{CCN}-100$, Droplet Measurement Technologies) which measured the number concentration of activated particles at different supersaturations (SS) in a range $0.17-1.20 \%$ (SS=RH-100\%). In parallel the number size distribution of the dried aerosol was measured with an SMPS system (TSI3071+TSI3785). The diameter at which the normalized cumulative size distribution equals the activated fraction is assumed to be the critical dry diameter $\left(D_{\text {crit }}\right)$, i.e. particles with a dry diameter bigger than this will be activated.

Light extinction by the SOA was studied using a continuous-wave cavity ring down (CW-CRD) aerosol spectrometer (Fig. 1f) which was described in details elsewhere (Lang-Yona et al., 2009). Briefly, an acousto-optic modulator (AOM) diffracts the $532 \mathrm{~nm}$ single mode laser beam and the 
first order diffraction is directed into a high finesse cavity. A piezoelectric ring, mounted at the light-entry side of the cavity modulates the cavity length until mode-matching between the cavity length and the laser mode is achieved. When the light intensity in the cavity reaches a certain level, the photomultiplier (PMT) placed at the other side of the cavity triggers off the AOM, and the exponential decay of the light intensity in the cavity is measured at about $400 \mathrm{~Hz}$ (LangYona et al., 2009). Particles in the cavity reduce the decay time compared to that of the empty cavity. The reduction and the particle number concentration yield the extinction efficiency $\left(Q_{\text {ext }}\right)$ at a specific wavelength $(\lambda)$ and specific size parameter $x(x=\pi D / \lambda)$ ), with $D$ being the geometric particle diameter. Measuring $Q_{\text {ext }}$ of spherical aerosols as a function of the particle size enables the retrieval of the complex reflective index (RI) by fitting the measured $Q_{\text {ext }}$ values to a Mie theory (Mie, 1908; Bohren and Huffman, 1998). About 0.8 standard liter per minute (SLM) flow containing monodisperse SOA were pumped into CRD system for extinction efficiency measurement. A CPC (TSI WCPC3786) was used for determining the particle concentration.

Extinction in the visible range $(532 \mathrm{~nm})$ becomes significant at particle diameters larger than $\sim 150 \mathrm{~nm}$. To produce SOA particles in this size range within the residence time of the air in our reaction chamber, we operated the plant chamber with 300-860 ppb Carbon (ppbC). This is equivalent to 30-86 ppb monoterpenes (MT), which is relatively high compared to atmospheric concentrations (Greenberg et al., 1999; Kesselmeier et al., 2002).

\section{Results and discussion}

\subsection{Plant emission patterns of volatile organic compounds}

The VOC emissions from Holm Oak were composed of monoterpenes (MT) $(97.5 \pm 1.2 \%)$, sesquiterpenes (SQT) $(0.4 \pm 0.8 \%)$, isoprene $(1.1 \pm 0.4 \%)$ and non-isoprenoid biogenic VOC $(1.1 \pm 0.4 \%)$ such as methyl salicylate. In the following the latter compounds are classified as other compounds. The finding that Holm Oak is mainly a monoterpene emitter is in good agreement with reported emissions in Europe (e.g. Staudt et al., 2002; Loreto, 2002, Loreto et al., 1998, 2000).

To test whether the Holm Oak emissions in our SOA formation experiment are typical for this species we performed additional experiments to determine the temperature and PPFD dependence of the monoterpene emissions (data not shown). The temperature and light dependencies are commonly described by phenomenological algorithms (Guenther et al., 1993; Staudt and Seufert, 1995; Schuh et al., 1997). For Quercus ilex L. emissions Bertin et al. (1997) described the light dependency using the algorithm of Guenther et al. (1993). Therein the light dependency $C_{\mathrm{L}}$ is param- eterized as a function of the photosynthetic photon flux density PPFD by the empirical parameters $\alpha$ and $C_{\mathrm{L} 1}$ as given in Eq. (1):

$C_{\mathrm{L}}=\frac{\alpha \cdot C_{\mathrm{L} 1} \cdot \mathrm{PPFD}}{\sqrt{1+\alpha^{2} \cdot \mathrm{PPFD}^{2}}}$

Monoterpene emissions from Holm Oak were negligible in darkness and they increased nearly linearly with increasing PPFD (Bertin et al., 1997; Staudt and Seufert, 1995). We found no significant saturation effects up to PPFD $=800 \mu \mathrm{mol} \mathrm{m}^{-2} \mathrm{~s}^{-1}$. Caused by the absence of a distinct saturation the cross dependencies of the parameters $\alpha$ and $C_{\mathrm{L} 1}$ in Eq. (1) were high, leading to uncertainties in the fit results. However, within the error limits we obtained the same parameters $\left(=0.0009 \pm 0.0007, C_{\mathrm{L} 1}=1.4 \pm 0.8\right)$ as those given by Bertin et al. (1997) $\left(\alpha=0.00147, C_{\mathrm{L} 1}=1.21\right)$.

Below $30^{\circ} \mathrm{C}$ the temperature dependencies of most monoterpene emissions were higher than those given in the literature, $\beta=0.2 \pm 0.03$ (i.e. $20 \%$ per degree) measured here compared to $\beta=0.12$ (Folkers et al., 2008; Staudt and Seufert, 1995). Nevertheless, these temperature dependencies were not exceedingly high. Very strong temperature dependencies were observed for ocimene emissions for which $\beta$ was found to be 0.3 (i.e. a $30 \%$ increase per degree). This observation confirms the findings of Staudt and Bertin (1998) who measured values between $\beta=0.32$ and $\beta=0.45$.

The SOA experiments were carried out between 30 and $35^{\circ} \mathrm{C}$, near the optimal enzyme activity, where the temperature dependence of cyclic MT emission is less than $10 \%$ per degree. However, ocimene emissions did still change with temperature at a high rate in accordance with previous observations (Staudt and Bertin, 1998). This strong increase of ocimene emissions with temperature led to a systematic change of the emission pattern. At $25^{\circ} \mathrm{C}$ the contribution of ocimenes to the total emissions was about $30 \%$ whereas at $35^{\circ} \mathrm{C}$ they contribute more than $53 \%$. Detailed speciation of the terpenes emitted is given in Fig. 2.

Overall, the emission trend found in this experiment is consistent with the behavior described in the literature (Bertin et al., 1997). This gives us confidence that the emission behavior was typical for Holm Oak and furthermore, that data obtained for the SOA formation potential of Holm Oak emissions may be considered as typical for this species.

\subsection{Size distribution of the aerosol particles}

The chambers operate as continuously stirred tank reactors (Mentel et al., 2009). Hence flush out (lowering the particle concentration for all size equally), condensation and coagulation (shifting the size distribution to higher diameters) occurred throughout the experiment. Other particle losses were negligible as the lifetime of the particle volume after stopping the chemical production is quite the same as the average residence time in the reaction chamber. During 


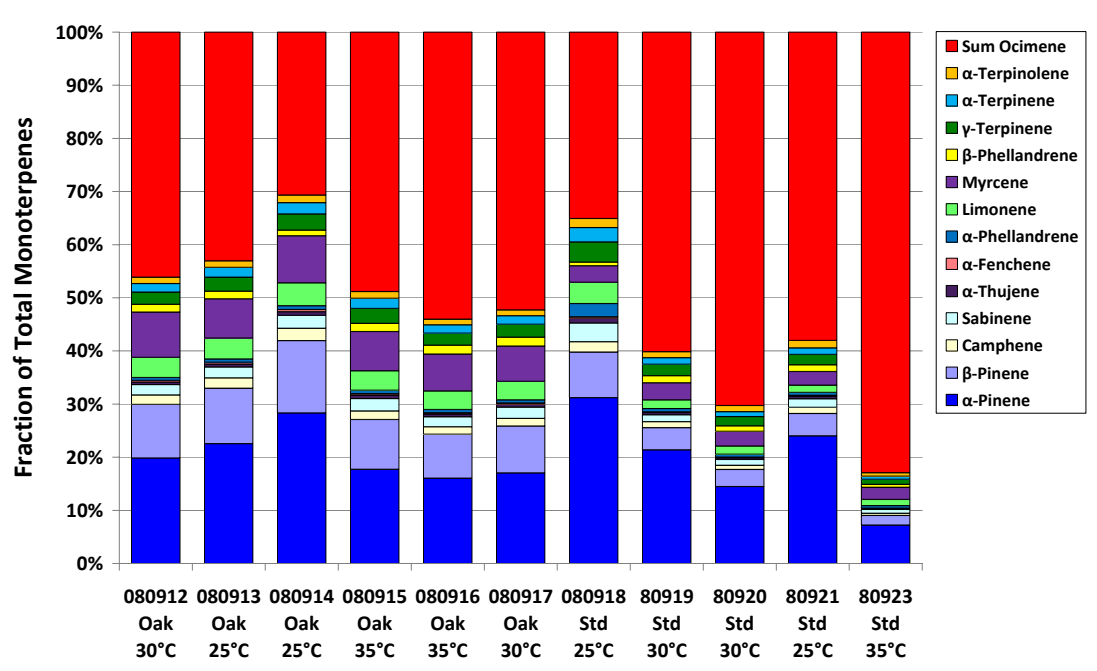

Fig. 2. Fractions of monoterpenes emitted from Holm Oak (Oak) and from a small Mediterranean stand (Std) determined by GC-MS. Experiment dates (yymmdd) are used to label the experiments. Temperatures in the plant chamber are denoted at the $\mathrm{x}$-axis.

the microphysical measurements which lasted up to $3 \mathrm{~h}$ the aerosol size distribution evolved in size and composition.

Figure 3 shows a sharp nucleation event shortly after the UV light is switched on followed by a second broad continuous nucleation of fresh particles. The particle size distributions were used to determine the particle growth rates and were converted into volume distributions in order to determine particle mass yields. Under our experimental conditions it took about $80 \mathrm{~min}$ to reach the maximum particle volume $\left(V_{\max }\right)$. Using an aerosol dynamical model we calculated that at the time $t_{\max }$ when $V_{\max }$ is observed, equivalent aerosol volume is already flushed out of the reaction chamber (Mentel et al., 2009). Therefore, in order to calculate the particle mass produced at $t_{\max }$ we multiplied $V_{\max }$ by a factor of 2 to correct for flush out. Furthermore we applied an effective density of $1.3 \mathrm{~g} \mathrm{~cm}^{-3}$ to convert from particle volume to particle mass. The effective density was determined by comparing the modal diameters of the SMPS volume and AMS mass (Kiendler-Scharr et al., 2009b). Figure 4 shows the total derived particle mass as a function of the mass concentration of MT and SQT that entered the reaction chamber. As described in detail in Mentel et al. (2009), virtually all MT and all SQT are consumed when $\sim 10^{7} \mathrm{~cm}^{-3} \mathrm{OH}$ radicals are present in the reaction chamber. The data point at the lowest mixing ratio is the result from experiments with the small Mediterranean stand. The generated particle mass depended linearly on the consumed mass of MT and SQT. This linearity holds up to $575 \mu \mathrm{g} \mathrm{m}^{-3}$, which is equivalent to about $860 \mathrm{ppbC}$. The slope of the linear correlation defines an incremental mass yield of $6.0 \pm 0.6 \%$. The positive $\mathrm{x}$-intercept of $28 \pm 27 \mathrm{~g} \mathrm{~m} \mathrm{~m}^{-3}$ (equivalent to $42 \mathrm{ppbC}$ ) which defines the nucleation threshold (Mentel et al., 2009) is not significant within the large errors. The fractional mass yield is similar to that found for Pine, $5.3 \pm 0.5 \%$ (Mentel et al., 2009). This

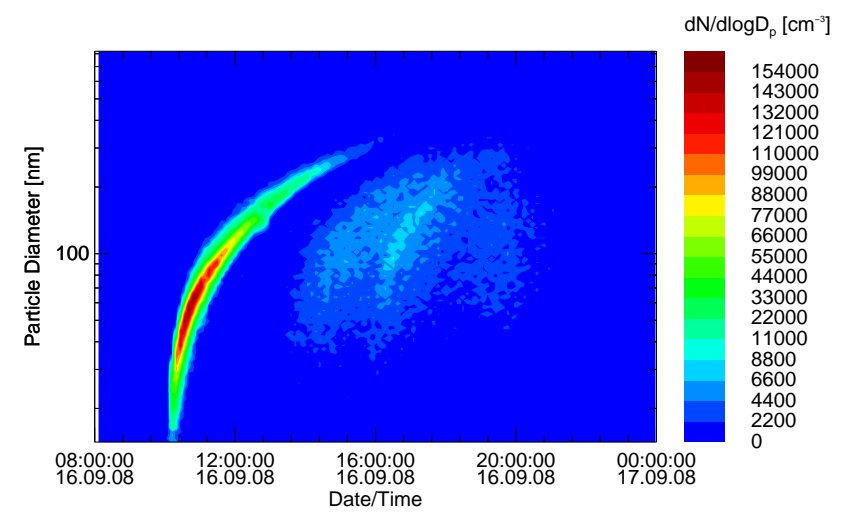

Fig. 3. Particle formation started at about $10: 00 \mathrm{~h}$ as soon as the VOC concentrations in reaction chamber exceeded the threshold level (VOC-induced experiment). When the condensational sink was reduced by flush out of the SOA, a consecutive set of smaller nucleation events (quasi-continuous nucleation) began at around 14:00 h. Hygroscopic growth was determined for particles with $D_{\text {dry }}=150 \mathrm{~nm}$ arising from the first narrow nucleation mode. CCN and optical measurements were carried out when the second mode was present.

implies that the SOA formation potential of Holm Oak emissions is similar to that of Pine, a Boreal tree species. Relating the maximum SOA mass to the amount of emitted VOC eliminates specific temperature or light intensity dependencies of VOC emissions or details of the specific emission patterns. We therefore suggest that the SOA formation potential of tree species just depends on the amount of emitted VOC as long as the emissions mainly consist of monoterpenes. 


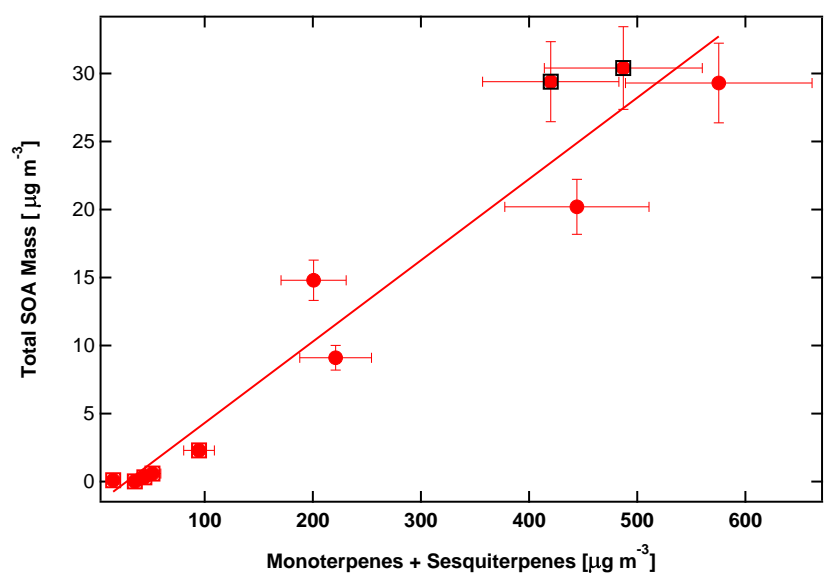

Fig. 4. Generated SOA mass as a function of the monoterpene and sesquiterpene mass concentration in the reaction chamber. The red circles are from the Holm Oak experiments, the red squares from the small Mediterranean stand. For the Mediterranean stand and the two Holm Oak experiments marked by the black squares the SOA was generated ox. induced. X-error bars are $\pm 15 \%$ and include the absolute GC calibration error. Y-error bars are $\pm 10 \%$ and include the precision of the SMPS measurement and the uncertainty in the SOA density. The slope of the linear regression line $(R=0.968)$ gave the incremental mass yield of $6.0 \pm 0.6 \%$. (The positive $x$-intercept would define a nucleation threshold of $28 \pm 27 \mu \mathrm{g} \mathrm{m}^{-3}$ equivalent to about 42 ppbC, but was not significant within the errors.)

A linear condensational growth was observed over several hours and growth rates characteristic for each experiment were therefore derived. Figure 5 shows the observed growth rates of Holm Oak emissions (red dots) and the low concentration experiments with the small Mediterranean stand (red squares). Due to the high VOC levels, condensational growth rates were $30-50 \mathrm{~nm} \mathrm{~h}^{-1}$. The calculated growth efficiency of Holm Oak emissions was $0.06 \pm 0.01 \mathrm{~nm} \mathrm{~h}^{-1}$ per ppbC. The low concentration experiment with the small Mediterranean stand (31-194 ppbC) was consistent with Holm Oak experiments. It is therefore likely that the results of incremental mass yields and growth efficiency for Holm Oak can be extrapolated to lower mixing ratios.

\subsection{Chemical composition of the aerosol particles}

The $\mathrm{O} / \mathrm{C}$ ratios of the SOA were derived in parallel to the measurements of the microphysical properties. The AMS particle mass spectra were dominated by organic compounds in the aerosols. Inorganic species, such as nitrate, sulfate, and ammonium, did not contribute to the particle mass. The variations in the precursor VOC pattern did not become manifest in marked differences in the mass spectral pattern. The same is true for the two types of SOA formation Ox-induced and $V O C$-induced. The AMS data were averaged over each of the 4 periods of the optical and microphysical measurements. Figure 6 shows an average mass spectrum for one of these periods. The total signal is distributed into ionic frag-

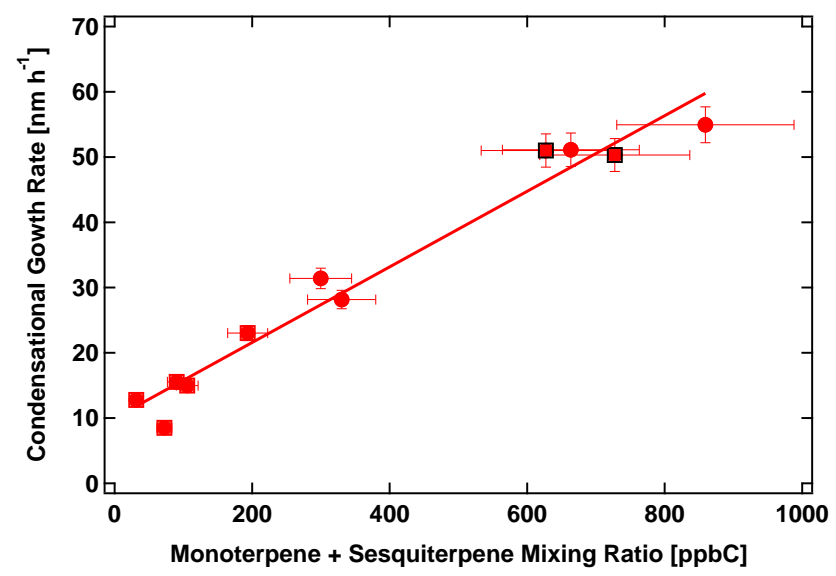

Fig. 5. The condensational growth rate of the first nucleation event is constant over several hours. The average condensational growth rate is plotted as a function of the monoterpene + sesquiterpene carbon mixing ratio in the reaction chamber. The red circles are from the Holm Oak experiments, the red squares are from the small Mediterranean stand. For the Mediterranean stand and the two Holm Oak experiments marked by the black squares the SOA was generated ox. induced. X-error bars are $\pm 15 \%$ and include the absolute calibration error. Y-error bars are $\pm 5 \%$ due to the precision of modal position of the number size distribution. The slope of the linear regression line $(R=0.98)$ gives a growth efficiency of $0.06 \pm 0.01 \mathrm{~nm} \mathrm{~h}^{-1}$ per ppbC (y-intercept $\left.=10.0 \pm 2 \mathrm{~nm} \mathrm{~h}^{-1}\right)$.

ments containing pure hydrocarbons $\left(\mathrm{C}_{\mathrm{x}} \mathrm{H}_{\mathrm{y}}^{+}\right)$, singly oxygenated hydrocarbons $\left(\mathrm{C}_{\mathrm{x}} \mathrm{H}_{\mathrm{y}} \mathrm{O}^{+}\right)$, and multiply oxygenated hydrocarbons $\left(\mathrm{C}_{\mathrm{x}} \mathrm{H}_{\mathrm{y}} \mathrm{O}_{\mathrm{z}>1}^{+}\right)$. The figure displays only carboncontaining fragments. $\mathrm{H}_{2} \mathrm{O}^{+}$ions arising from the fragmentation of organics are not included. The organic spectrum is dominated by the oxygenated fragments $\mathrm{C}_{2} \mathrm{H}_{3} \mathrm{O}^{+}$at $\mathrm{m} / 2,43$ and $\mathrm{CO}_{2}^{+}$at $\mathrm{m} / z 44$ as can be also seen from the highly mass resolved peaks in the inset in Fig. 6. The fractional contribution of the individual ions to the total signal at the integer $\mathrm{m} / \mathrm{z}$ 43 and 44 did not change during the CRD measurement intervals. The overall fractional amounts were $28 \%$ for $\mathrm{C}_{\mathrm{x}} \mathrm{H}_{\mathrm{y}}^{+}$, $52 \%$ for $\mathrm{C}_{\mathrm{x}} \mathrm{H}_{\mathrm{y}} \mathrm{O}^{+}$and $20 \%$ for $\mathrm{C}_{\mathrm{x}} \mathrm{H}_{\mathrm{y}} \mathrm{O}_{\mathrm{z}>1}^{+}$-fragments. The mass spectral patterns compare well to the average Holm Oak mass spectrum presented in (Kiendler-Scharr et al., 2009b).

The elemental analysis yields $\mathrm{O} / \mathrm{C}$ ratios of $0.57(+0.03 /-0.03)$ throughout all experiments. Because of the non-zero GF for the Holm Oak SOA at $65 \%$ RH, we may overestimate somewhat the $\mathrm{H}_{2} \mathrm{O}$ in the particles arising from the fragmentation of the organics. Hence also the $\mathrm{O} / \mathrm{C}$ ratio may be somewhat overestimated (see details in the Methods section). We calculated the maximum effect that would shift $\mathrm{O} / \mathrm{C}$ by -0.07 , assuming that all water taken up by the particles at RH $65 \%$ is detected by the AMS. However, the effect is smaller since water will evaporate on passing through the aerodynamic lens and expansion into the vacuum in the AMS. Consideration of the maximum systematic error leads to $\mathrm{O} / \mathrm{C}$ of $0.57(+0.03 /-0.1)$. 


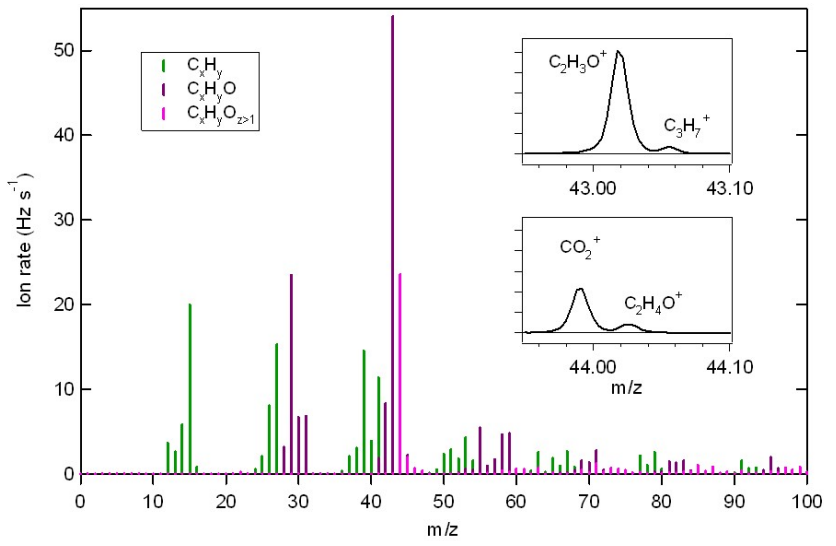

Fig. 6. AMS mass spectrum of SOA with unit mass resolution averaged over the period of an optical measurement. Only ion signals of carbon containing fragments are shown. The colors indicate the number of $\mathrm{O}$-atoms in the fragments: pure hydrocarbons (green, $\mathrm{C}_{\mathrm{x}} \mathrm{H}_{\mathrm{y}}$ ), singly oxygenated (violet, $\mathrm{C}_{\mathrm{x}} \mathrm{H}_{\mathrm{y}} \mathrm{O}$ ) and multiply oxygenated (magenta, $\mathrm{C}_{\mathrm{x}} \mathrm{H}_{\mathrm{y}} \mathrm{O}_{\mathrm{z}>1}$ ). The inserts show the ion signals, the fitted peaks, and the residuum as well as the representation at unit mass resolution in the mass spectrum. The ion signal at $\mathrm{m} / \mathrm{z}$ 43 is composed of a singly oxygenated fragment, whereas the signal at $m / z, 44$ is mainly composed of the $\mathrm{CO}_{2}^{+}$with a small but significant contribution of a singly oxygenated fragment.

\subsection{Microphysical properties of the aerosol particles}

\subsubsection{Hygroscopic growth and CCN measurements}

Humidograms of the SOA in the hydration mode as measured in the different experiments are shown in Fig. 7. Hygroscopic growth factors at 90 and $95 \%$ RH are given in Table 2. For each experiment particles with diameters of $150 \mathrm{~nm}$ were selected out of the first nucleated mode. Due to the different condensational growth rates the measurements started between $50 \mathrm{~min}$ and $2.5 \mathrm{~h}$ after the onset of nucleation whenever sufficient $150 \mathrm{~nm}$ particles were available. The measurement time for each hydration curve was $60 \mathrm{~min}$, during which the SOA continued to grow (compare Fig. 3).

Generally, SOA produced from oxidation of Holm Oak VOC emissions were slightly hygroscopic. The average GF for $150 \mathrm{~nm}$ particles was $1.13 \pm 0.03$ at $90 \% \mathrm{RH}$ and $1.21 \pm 0.02$ at $95 \%$ RH. $250 \mathrm{~nm}$ particles selected out of the first nucleation mode were on average slightly more hygroscopic with $\mathrm{GF}(90 \%)=1.18 \pm 0.01$ and $\mathrm{GF}(95 \%)=1.28 \pm 0.01$. There was no clear trend related to the different experimental conditions of VOC-induced or Ox.-induced SOA formation. The observed values are comparable with measurements of Varutbangkul et al. (2006) who observed $\mathrm{GF}(85 \%)$ in a range of $1.06-1.1$ for SOA from several monoterpenes. Good et al. (2010) reported $\mathrm{GF}(90 \%)$ ) for SOA generated from pure $\alpha$ pinene at $90 \mathrm{ppbC}$ initial concentration which increased after $2-8 \mathrm{~h}$ from 1.1 to 1.2 ( $H_{\mathrm{MAN}}$ instrument). If $370 \mathrm{ppC}$ initial $\alpha$-pinene was used the $\mathrm{GF}(90 \%)$ were lower and raised from
Table 1. Overview over the experiments and experimental conditions.

\begin{tabular}{llcccl}
\hline Exp. & Species & $\begin{array}{c}\text { BVOC } \\
{[\mathrm{ppbC}]}\end{array}$ & $\begin{array}{c}\mathrm{BVOC} \\
{\left[\mu \mathrm{g} \mathrm{m}^{-3}\right]}\end{array}$ & $\begin{array}{c}T_{\mathrm{PC}} \\
{ }^{\circ} \mathrm{C}\end{array}$ & Comment \\
\hline 080912 & Oak* & 627 & 420 & 30 & Ox.-induced \\
080913 & Oak & 330 & 221 & 25 & VOC-induced \\
080914 & Oak & 300 & 201 & 25 & VOC-induced \\
080915 & Oak & 859 & 575 & 35 & VOC-induced \\
080916 & Oak & 664 & 444 & 35 & VOC-induced \\
080917 & Oak & 728 & 487 & 30 & Ox.-induced \\
080918 & Std** & 31.4 & 15.4 & 25 & Ox.-induced \\
080919 & Std & 90.3 & 44.3 & 30 & Ox.-induced \\
080920 & Std & 106 & 51.8 & 30 & Ox.-induced \\
080921 & Std & 72.4 & 35.5 & 25 & Ox.-induced \\
080923 & Std & 194 & 94.8 & 35 & Ox.-induced \\
\hline
\end{tabular}

* Oak: single Holm Oak (Quercus Ilex L.);

** Std: 3 Pistacia palaestina (Pistacia palaestina L.), 3 Aleppo Pine (Pinus halepensis L.) and 1 Palestine Oak (Quercus calliprinos L.).

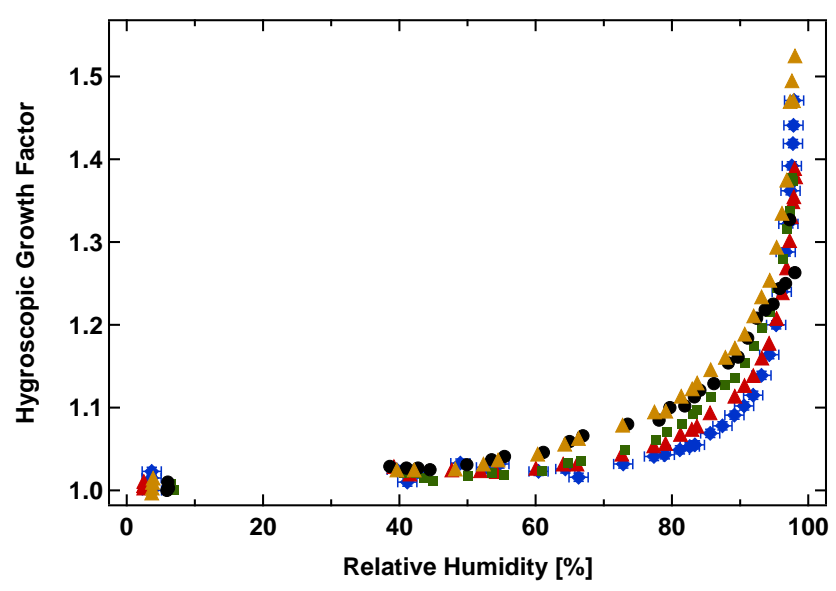

Fig. 7. Hygroscopic growth factor as a function of the relative humidity for particles of $D_{\mathrm{dry}}=150 \mathrm{~nm}$ selected from the first nucleation mode. The blue (080912) and black (080917) humidgrams were measured in the Ox.-induced experiments, red (080915) and green (080916) humidograms stem from VOC-induced experiments. A humidogram for $250 \mathrm{~nm}$ particles (080915) is shown in yellow. (Experiment dates in parenthesis are the same as in $\mathrm{Ta}-$ ble 1.) Experimental errors are shown for the blue curve $\sigma_{\mathrm{RH}}=1.4 \%$, $\sigma_{\mathrm{GF}}=0.005$, error bar are representative for all measurements. The variation of the humidograms is not related to the experimental conditions in a systematic way. The $250 \mathrm{~nm}$ particles, which are also more aged, showed the largest hygroscopicity.

1.06 to 1.12 for the same time period (Good et al., 2010). In their review Swietlicki et al. (2008) summarize GF(90\%) for field studies in rural areas. Our GF( $90 \%)$ is at the low end of their less hygroscopic group (LH). Similar values were observed at many locations, e.g. in the Po-Valley at San Pietro Capodifiume (1.10 for $150 \mathrm{~nm}$ particles). 
Table 2. Hygroscopic growth factor at $90 \%$ and $95 \% \mathrm{RH}$ for all experiments.

\begin{tabular}{ccccl}
\hline $\begin{array}{c}\text { Time since event } \\
\text { start [hours] }\end{array}$ & $\begin{array}{c}D_{\text {dry }} \\
{[\mathrm{nm}]}\end{array}$ & $\begin{array}{c}\text { GF } \\
(95 \%)\end{array}$ & $\begin{array}{c}\text { GF } \\
(90 \%)\end{array}$ & $\begin{array}{l}\text { Date/ } \\
\text { Comment }\end{array}$ \\
\hline 0.5 & 150 & 1.19 & 1.10 & $080912 /$ Ox.-induced \\
2.1 & 159 & 1.20 & 1.12 & $080915 /$ VOC-induced \\
4.0 & 250 & 1.28 & 1.18 & $080915 /$ VOC-induced \\
2.3 & 150 & 1.23 & 1.15 & $080916 /$ VOC-induced \\
2.1 & 150 & 1.23 & 1.17 & $080917 /$ Ox.-induced \\
\hline
\end{tabular}

The accuracy of the CCN measurements was affected during the first few hours by the fast dynamics of the narrow size distribution, leading to a rather large scatter in the $D_{\text {crit }}$ during the first nucleation event. After 4 to $5 \mathrm{~h}$, particles in the second nucleation event (Fig. 3) had lower growth rate allowing for more reliable CCN measurements. $D_{\text {crit }}$ remained constant in these experiments which is consistent with the constant $\mathrm{O} / \mathrm{C}$ ratios obtained by the AMS.

$D_{\text {crit }}$ from each set of supersaturations (SS) are compared in Fig. 8 (left axis, solid triangles). The data was recorded in the time period 6 to $7 \mathrm{~h}$ after the initiation of the first nucleation. For each $D_{\text {crit }}$, the hygroscopicity parameter $\kappa$ was calculated, assuming the surface tension of water (Petters and Kreidenweis, 2007) and is also shown in Fig. 8 (right axis, open circles). The $\kappa$ values were in the range of 0.04 to 0.1 . In all experiments, $\kappa$ was not constant but rather decreased with increasing SS.

The CCN measurements at low SS reflect the aged particles at the larger edge of the size distribution while in high SS measurements most of the particles including fresh ones were activated. This is in accordance with the observation that $250 \mathrm{~nm}$ particles have slightly higher GF. Considering the condensational growth rates shown in Fig. 5, the $250 \mathrm{~nm}$ particles are approximately $2-3 \mathrm{~h}$ older than the $150 \mathrm{~nm}$ particles. During their growth, higher oxidized compounds can condense onto the particles in addition to possible other aging processes that may take place. These processes conceivably lead to a different composition for the larger (and "older" particles). By the time particles from the first mode reach $250 \mathrm{~nm}$, the second nucleation event begins in the reaction chamber, adding fresh particles that probably have lower $\mathrm{O} / \mathrm{C}$-ratios. We note that in contrast to $\mathrm{CCN}$ and hygroscopicity measurements, the AMS data were reported as average over the entire size distribution (which has contributions of fresh and aged particles) and hence the average $\mathrm{O} / \mathrm{C}$ ratio is almost constant. Similar to in the atmosphere we generated external mixed aerosols of fresh and continuously aged SOA. Hence, the $\mathrm{O} / \mathrm{C}$ ratios averaged over the whole size distribution cannot reflect detailed changes in the microphysical properties of parts of the size distribution.

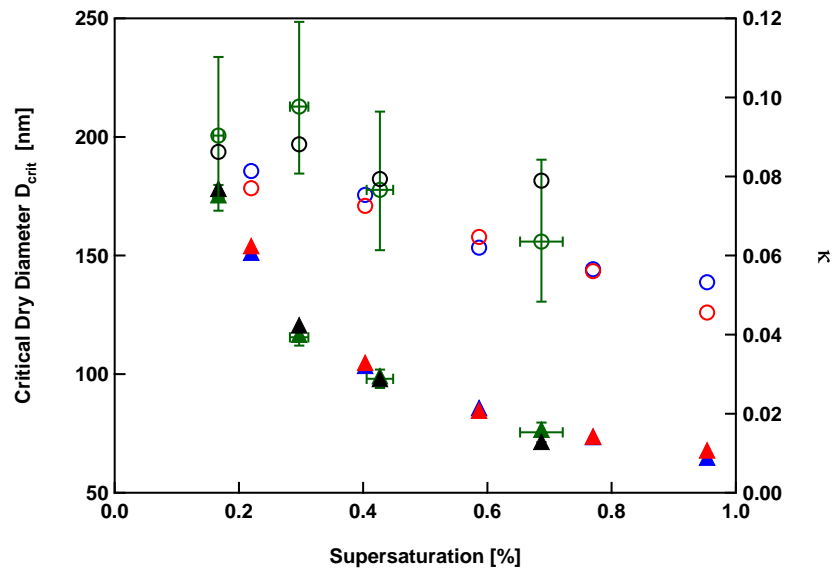

Fig. 8. Critical dry diameter for activation $\left(D_{\text {crit }}\right)$ as a function of the supersaturation (solid triangles, left axis). Calculated $\kappa$ from one parameters Köhler equation (open circles, right axis). The blue (080912) and black (080917) data was measured in the $O x$. induced experiments, red (080913) and green (080916) data stem form $V O C$-induced experiments. (Numbers in parenthesis refer to the experiment date). Typical errors are indicated for some cases. All data 6 to $7 \mathrm{~h}$ after the first nucleation started and the second nucleation mode is present. The $\kappa$ are larger at small supersaturations where particles with larger diameter (and more aged) are probed.

\subsubsection{CW-CRD aerosol spectrometer measurements}

Since extinction at a wavelength of $532 \mathrm{~nm}$ becomes significant only at particle diameters larger than $\sim 150 \mathrm{~nm}$ we applied mixing ratios of 300-860 ppbC and waited 3-4 h until sufficient particles with diameters larger than $150 \mathrm{~nm}$ were available.

In Fig. 9, measurements of $Q_{\text {ext }}$ of Holm Oak SOA are shown as a function of size parameter. The points represent the $Q_{\text {ext }}$ measured with the CW-CRD and the solid lines represent the Mie curve generated by the retrieved RI (Dinar et al., 2008; Lang-Yona et al., 2009; Riziq, 2008; Riziq et al., 2007; Spindler et al., 2007). Figure 9 (red, $n=(1.53 \pm 0.08)+i(0.00 \pm 0.05))$ shows measurements for $V O C$-induced SOA formed by raising the VOC emissions of the Holm Oak above the nucleation threshold in the presence of $\mathrm{OH}$ and $\mathrm{O}_{3}$ in the reaction chamber. Ox.-induced particles showed similar RI, $n=(1.53 \pm 0.06)+i(0.00 \pm 0.04)$ (Fig. 9, blue). The retrieved complex refractive indices indicate relatively high scattering values in the real part compared to hydrocarbon organics, which range between 1.411.54 (Lide, 1997). The complex part of the refractive index is zero, indicating that these fresh biogenic SOA do not absorb radiation at $532 \mathrm{~nm}$. The slightly high value of the particles' real part might be attributed to their relatively small diameter, getting closer to the Rayleigh regime, leading to overestimation of the real part values (Bohren and Huffman, 1998; Bohren and Clothiaux, 2006). The negligible absorption is attributed to the relatively fresh particles which are mainly 


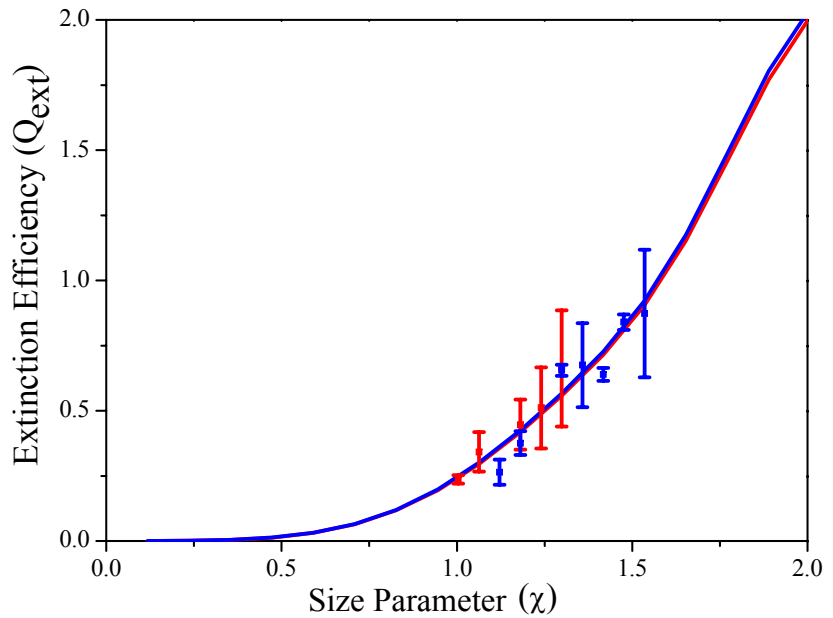

Fig. 9. Extinction efficiency $\left(Q_{\text {ext }}\right)$ as a function of size parameter $(\chi)$ for SOA formed by VOC-induced (red) and Ox.-induced (blue) particle formation. The derived complex refractive indices are $n=(1.53 \pm 0.08)+i(0.00 \pm 0.05)$ for SOA from VOC-induced experiments and $n=(1.53 \pm 0.06)+i(0.00 \pm 0.04)$ for SOA from $O x$.induced experiments. The squares represent the measurements and the lines are Mie curves calculated on basis of the derived refractive indices.

composed of low molecular weight oxidation products of MT with an $\mathrm{O} / \mathrm{C}$ ratio of about 0.6. In the atmosphere the absorption may increase at later stages, if polymers are formed (Dinar et al., 2008; Rudich et al., 2007). However, the lifetime of the aerosols in our experiments is not long enough to observe substantial ageing and polymer formation. These findings are consistent with previous measurements reported by Dinar et al. (2008) showing negligible absorption in fresh SOA in a rural environment.

The similar optical behavior calculated for the two type of experiment, VOC-induced and Ox.-induced is in line with the similar hygroscopicity and $\mathrm{CCN}$ behavior in both experiments, as described in Sect. 3.4.1.

The CRD measurements suffer from relatively large measurement errors, most likely due to low particle concentrations $\left(150-200 \mathrm{~cm}^{-3}\right)$, and the low size parameter which we could achieve in the present setup. Smaller errors should be expected for shorter wavelengths that lead to higher size parameters.

\section{Summary and conclusions}

This study focused on SOA formation from VOC emitted by Holm Oak (Quercus ilex L.), a common Mediterranean tree. More than $97 \%$ of the Holm Oak VOC emissions are composed of monoterpenes. The SOA had similar hygroscopic and optical properties when formed in different experimental procedures. The incremental mass yield determined from the combined data sets of Holm Oak and the small
Mediterranean stand (Pistacia palaestina, Pinus halepensis, and Quercus calliprinos) was $6 \pm 0.6 \%$, the calculated growth efficiencies were $0.06 \pm 0.01 \mathrm{~nm} \mathrm{~h}^{-1}$ per ppbC, quite similar to the incremental mass yield and the growth efficiency of Pine tree, a Boreal species. The growth rates were determined after the initial aerosols nucleated. Therefore the linear growth observed in the chamber is conceptually similar to growth on pre-existing atmospheric aerosol. In addition since the SOA yield measured in the chamber matches yield observations in the Boreal environment (Mentel et al., 2009; Tunved et al., 2008) we suggest that the process we observe for the Mediterranean species is also representative and the values for aerosol yield are relevant to the atmosphere and could be applied to model calculations

The increase of Holm oak emissions with temperature (20\% per degree, see supplementary material and Staudt and Bertin, 1998) was stronger than that described for Boreal tree species (ca. 10\% per degree, e.g. Guenther et al., 1993, 1995; Janson et al., 1993; Shao et al., 2001). The incremental yield of $6 \%$ for SOA formation found for monoterpenes from Mediterranean species is nearly the same as for Boreal species (5.7\%, Mentel et al., 2009), independent of the BVOC patterns or the detailed reaction conditions. Therefore, assuming the same atmospheric conditions for particle formation and neglecting stress impacts on the plants' BVOC emissions, a similar temperature increase for Holm oak and a Boreal species would cause different increases in particle formation. For example a 2 degree increase would result in a 50\% SOA mass increase for Holm Oak caused by the high temperature dependence of ocimene emissions. For Boreal forest trees the increase would be only $20 \%$. Volatility measurements show that the volume of SOA decreases by only $20 \%$ per 50 degree change in temperature (Jonsson et al., 2007), suggesting that the SOA increase due to increased emission would be the dominant effect under the projected climate change. However, this supposition awaits further experiments and modeling efforts considering also changes of the boundary conditions.

The composition of the SOA from Holm Oak emissions as derived from aerosol mass spectra resembled previously published data of biogenic SOA (Kiendler-Scharr et al., 2009b). The average $\mathrm{O} / \mathrm{C}$ ratio is $0.57(+0.03 /-0.1)$ with an average GF of $1.13 \pm 0.03$ at $90 \% \mathrm{RH}$ and critical diameter of $100 \pm 4 \mathrm{~nm}$ at a supersaturation of $0.4 \%$. The hygroscopic growth and the $\mathrm{CCN}$ measurements indicate that aged particles were somewhat more hygroscopic than fresh ones. The SOA formed by the oxidation of Holm Oak VOC efficiently scatter visible radiation, with no absorption at $532 \mathrm{~nm}$. Lack of absorption is attributed to the low molecular weight products of the monoterpene oxidation and negligible oligomerization. The invariance of the microphysical and optical properties of the SOA particles despite of changing emission patterns and reaction conditions (VOC-induced/Ox.-induced) suggests that these also will not be too different in a future warmer climate compared to now. Note that we can only 
investigate fresh particles in our setup. Ageing on atmospheric time scale of days may lead to absorptive particles by oligomerization reactions and to more hygroscopic particles by oxidation reactions - today and in a future climate.

The scattering character of the measured SOA may lead to a regional reduction in the direct solar radiation intensity reaching the Earth's surface, possibly contributing to the climatic cooling effect. However, the biogenic SOA can lead to increased diffuse radiation, which was previously shown to significantly increase yields of certain crops (Chameides et al., 1999). It was recently shown that variations in the fraction of diffuse radiation, associated with "global dimming", enhanced the land carbon sink by approximately $25 \%$ between 1960 and 1999 (Mercado et al., 2009). Thus, enhanced biogenic SOA formation due to elevated temperatures may enhance the fraction of diffuse radiation reaching the Earth due to scattering of incoming solar radiation and interactions with clouds. This effect may partly counterbalance the reduction in diffuse radiation projected for the twenty-first century due to reductions in sulfate aerosols (Mercado et al., 2009), hence extending the period of "diffuse-radiation" fertilization effects, at least on regional scales. However, the quantitative impact of this effect is based on the quantitative changes of VOC emission strengths. Such changes are not only caused by increases in temperature but also by stress impacts on plans at elongated drought and heat episodes.

\section{Supplementary material related to this article is available online at: http://www.atmos-chem-phys.net/10/7253/2010/ acp-10-7253-2010-supplement.pdf.}

Acknowledgements. We gratefully acknowledge the support by the European Commission (IP-EUCAARI, Contract No. 036833-2, by the ESF (INTROP) and by the Israel Science Foundation (grants 1527/07 and 196/08). Yinon Rudich acknowledges financial support by the Helen and Martin Kimmel Award for Innovative Investigation.

Edited by: M. Ammann

\section{References}

Abo Riziq, A., Erlick, C., Dinar, E., and Rudich, Y.: Optical properties of absorbing and non-absorbing aerosols retrieved by cavity ring down (CRD) spectroscopy, Atmos. Chem. Phys., 7, 15231536, doi:10.5194/acp-7-1523-2007, 2007.

Abo Riziq, A., Trainic, M., Erlick, C., Segre, E., and Rudich, Y.: Extinction efficiencies of coated absorbing aerosols measured by cavity ring down aerosol spectrometry, Atmos. Chem. Phys., 8, 1823-1833, doi:10.5194/acp-8-1823-2008, 2008.

Aiken, A. C., DeCarlo, P. F., and Jimenez, J. L.: Elemental analysis of organic species with electron ionization high-resolution mass spectrometry, Anal. Chem., 79, 8350-8358, 2007.

Aiken, A. C., DeCarlo, P. F., Kroll, J. H., Worsnop, D. R., Huffman, J. A., Docherty, K. S., Ulbrich, I. M., Mohr, C., Kimmel,
J. R., Sueper, D., Sun, Y., Zhang, Q., Trimborn, A., Northway, M., Ziemann, P. J., Canagaratna, M. R., Onasch, T. B., Alfarra, M. R., Prevot, A. S. H., Dommen, J., Duplissy, J., Metzger, A., Baltensperger, U., and Jimenez, J. L.: O/C and OM/OC ratios of primary, secondary, and ambient organic aerosols with high-resolution time-of-flight aerosol mass spectrometry, Environ. Sci. Technol., 42, 4478-4485, 2008.

Albrecht, B. A.: Aerosols, cloud microphysics, and fractional cloudiness, Science, 245, 1227-1230, 1989.

Allan, J. D., Delia, A. E., Coe, H., Bower, K. N., Alfarra, M. R., Jimenez, J. L., Middlebrook, A. M., Drewnick, F., Onasch, T. B., Canagaratna, M. R., Jayne, J. T., and Worsnopf, D. R.: A generalised method for the extraction of chemically resolved mass spectra from aerodyne aerosol mass spectrometer data, J. Aerosol Sci., 35, 909-922, 2004.

Barth, M.: Couling between land ecosystems and the atmospheric hydrologic cycle through biogenic aerosol pathways, B. Am. Meteorol. Soc., 86, 1738-1742, 2005.

Bertin, N., Staudt, M., Hansen, U., Seufert, G., Ciccioli, P., Foster, P., Fugit, J. L., and Torres, L.: Diurnal and seasonal course of monoterpene emissions from Quercus ilex (L.) under natural conditions application of light and temperature algorithms, Atmos. Environ., 31, 135-144, 1997.

Bohren, C. F. and Clothiaux, E. E.: Fundamentals of atmospheric radiation: an introduction with 400 problems, Wiley-VCH, New York, 2006.

Bohren, C. F. and Huffman, D. R: Absorption and Scattering of Light by Small Particles, Wiley VCH, New York, 1998.

Buchholz, A.: Entwicklung eines Geräts zur Untersuchung des hygroskopischen Wachstums von organischen Aerosolen, Diploma thesis, Department of Chemistry, University of Cologne, Cologne, Germany, 76 pp., 2007.

Chameides, W. L., Yu, H., Liu, S. C., Bergin, M., Zhou, X., Mearns, L., Wang, G., Kiang, C. S., Saylor, R. D., Luo, C., Huang, Y., Steiner, A., and Giorgi, F.: Case study of the effects of atmospheric aerosols and regional haze on agriculture: An opportunity to enhance crop yields in China through emission controls?, P. Natl. Acad. Sci. USA, 96, 13626-13633, 1999.

Chen, Y., Li, Q. B., Kahn, R. A., Randerson, J. T., and Diner, D. J.: Quantifying aerosol direct radiative effect with Multiangle Imaging Spectroradiometer observations: Top-of-atmosphere albedo change by aerosols based on land surface types, J. Geophys. Res., 114, D02109, doi:10.1029/2008JD010754, 2009.

DeCarlo, P. F., Kimmel, J. R., Trimborn, A., Jayne, J. T., Aiken, A. C., Gonin, M., Fuhrer, K., Horvath, T., Docherty, K. S., Worsnop, D. R., and Jimenez, J. L.: A Field-Deployable High-Resolution Time-of-Flight Aerosol Mass Spectrometer, Anal. Chem., 78, 138, 2006.

Dinar, E., Riziq, A. A., Spindler, C., Erlick, C., Kiss, G., and Rudich, Y.: The complex refractive index of atmospheric and model humic-like substances (HULIS) retrieved by a cavity ring down aerosol spectrometer (CRD-AS), Faraday Discussions, 137, 279-295, 2008.

Folkers, A., Huve, K., Ammann, C., Dindorf, T., Kesselmeier, J., Kleist, E., Kuhn, U., Uerlings, R., and Wildt, J.: Methanol emissions from deciduous tree species: dependence on temperature and light intensity, Plant Biol., 10, 65-75, 2008.

Greenberg, J. P., Guenther, A., Zimmerman, P., Baugh, W., Geron, C., Davis, K., Helmig, D., and Klinger, L. F.: Tethered balloon 
measurements of biogenic VOCs in the atmospheric boundary layer, Atmos. Environ., 33, 855-867, 1999.

Guenther, A., Hewitt, C. N., Erickson, D., Fall, R., Geron, C., Graedel, T., Harley, P., Klinger, L., Lerdau, M., McKay, W. A., Pierce, T., Scholes, B., Steinbrecher, R., Tallamraju, R., Taylor, J., and Zimmerman, P.: A global model of natural volatile organic compound emissions, J. Geophys. Res., 100, 8873-8892, 1995.

Guenther, A. B., Zimmerman, P. R., Harley, P. C., Monson, R. K., and Fall, R.: Isoprene and Monoterpene Emission Rate Variability: Model Evaluations and Sensitivity Analyses, J. Geophys. Res., 98, 12609-12617, 1993.

Hallquist, M., Wenger, J. C., Baltensperger, U., Rudich, Y., Simpson, D., Claeys, M., Dommen, J., Donahue, N. M., George, C., Goldstein, A. H., Hamilton, J. F., Herrmann, H., Hoffmann, T., Iinuma, Y., Jang, M., Jenkin, M. E., Jimenez, J. L., Kiendler-Scharr, A., Maenhaut, W., McFiggans, G., Mentel, Th. F., Monod, A., Prévôt, A. S. H., Seinfeld, J. H., Surratt, J. D., Szmigielski, R., and Wildt, J.: The formation, properties and impact of secondary organic aerosol: current and emerging issues, Atmos. Chem. Phys., 9, 5155-5236, doi:10.5194/acp-95155-2009, 2009.

Hao, L. Q., Yli-Pirilä, P., Tiitta, P., Romakkaniemi, S., Vaattovaara, P., Kajos, M. K., Rinne, J., Heijari, J., Kortelainen, A., Miettinen, P., Kroll, J. H., Holopainen, J. K., Smith, J. N., Joutsensaari, J., Kulmala, M., Worsnop, D. R., and Laaksonen, A.: New particle formation from the oxidation of direct emissions of pine seedlings, Atmos. Chem. Phys., 9, 8121-8137, doi:10.5194/acp9-8121-2009, 2009.

Heiden, A. C., Hoffmann, T., Kahl, J., Kley, D., Klockow, D., Langebartels, C., Mehlhorn, H., Sandermann, H., Schraudner, M., Schuh, G., and Wildt, J.: Emission of volatile organic compounds from ozone-exposed plants, Ecol. Appl., 9, 1160-1167, 1999.

Janson, R. W.: Monoterpene Emissions From Scots Pine and Norwegian Sspruce, J. Geophys. Res., 98, 2839-2850, 1993.

Jonsson, A. M., Hallquist, M., and Saathoff, H.: Volatility of secondary organic aerosols from the ozone initiated oxidation of alpha-pinene and limonene, J. Aerosol Sci., 38, 843-852, 2007.

Kaufman, Y. J., Tanre, D., and Boucher, O.: A satellite view of aerosols in the climate system, Nature, 419, 215-223, 2002.

Kaufman, Y. J., Koren, I., Remer, L. A., Rosenfeld, D., and Rudich, Y.: The effect of smoke, dust, and pollution aerosol on shallow cloud development over the Atlantic Ocean, P. Natl. Acad. Sci. USA, 102, 11207-11212, 2005.

Kaufman, Y. J. and Koren, I.: Smoke and pollution aerosol effect on cloud cover, Science, 313, 655-658, 2006.

Kesselmeier, J., Schäfer, L., Ciccioli, P., Brancaleoni, E., Cecinato, A., Frattoni, M., Foster, P., Jacob, V., Denis, J., Fugit, J. L., Dutaur, L., and Torres, L.: Emission of monoterpenes and isoprene from a Mediterranean oak species Quercus ilex L. measured within the BEMA (Biogenic Emissions in the Mediterranean Area) project, Atmos. Environ., 30, 1841-1850, 1996.

Kesselmeier, J., Kuhn, U., Rottenberger, S., Biesenthal, T., Wolf, A., Schebeske, G., Andreae, M. O., Ciccioli, P., Brancaleoni, E., Frattoni, M., Oliva, S. T., Botelho, M. L., Silva, C. M. A., and Tavares, T. M.: Concentrations and species composition of atmospheric volatile organic compounds (VOCs) as observed during the wet and dry season in Rondonia (Amazonia), J. Geophys.
Res., 107, 8053, doi:10.1029/2000JD000267, 2002.

Kiendler-Scharr, A., Wildt, J., Dal Maso, M., Hohaus, T., Kleist, E., Mentel, T. F., Tillmann, R., Uerlings, R., Schurr, U., and Wahner, A.: New particle formation in forests inhibited by isoprene emissions, Nature, 461, 381-384, 2009a.

Kiendler-Scharr, A., Zhang, Q., Hohaus, T., Kleist, E., Mensah, A., Mentel, T. F., Spindler, C., Uerlings, R., Tillmann, R., and Wildt, J.: Aerosol mass spectrometric features of biogenic SOA: Observations from a plant chamber and in rural atmospheric environments, Environ. Sci Technol., 43, 8166-8172, 2009b.

Kulmala, M., Vehkamaki, H., Petaja, T., Dal Maso, M., Lauri, A., Kerminen, V. M., Birmili, W., and McMurry, P. H.: Formation and growth rates of ultrafine atmospheric particles: a review of observations, J. Aerosol Sci., 35, 143-176, 2004a.

Kulmala, M., Suni, T., Lehtinen, K. E. J., Dal Maso, M., Boy, M., Reissell, A., Rannik, Ü., Aalto, P., Keronen, P., Hakola, H., Bäck, J., Hoffmann, T., Vesala, T., and Hari, P.: A new feedback mechanism linking forests, aerosols, and climate, Atmos. Chem. Phys., 4, 557-562, doi:10.5194/acp-4-557-2004, 2004b.

Lang-Yona, N., Rudich, Y., Segre, E., Dinar, E., and Abo-Riziq, A.: Complex refractive indices of aerosols retrieved by Continuous Wave-Cavity Ring Down aerosol spectrometer, Anal. Chem., 81, 1762-1769, 2009

Lide, D. R.: Handbook of Chemistry and Physics, 78th ed., 1997.

Liu, P., Ziemann, P. J., Kittelson, D. B., and McMurry, P. H.: Generating particle beams of controlled dimensions and divergence: I. Theory of particle motion in aerodynamic lenses and nozzle expansions, Aerosol Sci. Tech., 22, 293-313, 1995.

Lohmann, U. and Feichter, J.: Global indirect aerosol effects: a review, Atmos. Chem. Phys., 5, 715-737, doi:10.5194/acp-5-7152005, 2005.

Loreto, F., Forster A., Durr M., Csiky O., and Seufert G.: On the monoterpene emission under heat stress and on the increased thermotolerance of leaves of Quercus ilex L. fumigated with selected monoterpenes, Plant Cell Environ., 21, 101-107, 1998.

Loreto, F: Distribution of isoprenoid emitters in the Quercus genus around the world: chemo - taxonomical implications and evolutionary considerations based on the ecological function of the trait, Perspect. Plant Ecol., 5, 185-192, 2002.

Loreto, F., Ciccioli, P., Brancaleoni, E., Frattoni, M., and Delfine, S.: Incomplete $13 \mathrm{C}$ labelling of alpha-pinene content of Quercus ilex leaves and appearance of unlabelled $\mathrm{C}$ in alpha -pinene emission in the dark, Plant Cell Environ., 23, 229-234, 2000.

Manes, F., Seufert, G., and Vitale M.: Ecophysiological studies of Mediterranean plant species at the Castelporziano estate, Atmos. Environ., 31, 51-60, 1997.

Mentel, Th. F., Wildt, J., Kiendler-Scharr, A., Kleist, E., Tillmann, R., Dal Maso, M., Fisseha, R., Hohaus, Th., Spahn, H., Uerlings, R., Wegener, R., Griffiths, P. T., Dinar, E., Rudich, Y., and Wahner, A.: Photochemical production of aerosols from real plant emissions, Atmos. Chem. Phys., 9, 4387-4406, doi:10.5194/acp9-4387-2009, 2009

Mercado, L. M., Bellouin, N., Sitch, S., Boucher, O., Huntingford, C., Wild, M., and Cox, P. M.: Impact of changes in diffuse radiation on the global land carbon sink, Nature, 458, 1014-1018, 2009.

Mie, G.: Beiträge zur Optik trüber Medien, speziell kolloidaler Metallösungen, Ann. Phys., 330, 377-445, 1908.

Monks, P. S., Granier, C., Fuzzi, S., Stohl, A., Williams, M., Aki- 
moto, H., Amman, M., Baklanov, A., Baltensperger, U., Bey, I., Blake, N., Blake, R. S., Carslaw, K., Cooper, O. R., Dentener, F., Fowler, D., Fragkou, E., Frost, G., Generoso, S., Ginoux, P., Grewe, V., Guenther, A., Hansson, H. C., Henne, S., Hjorth, J., Hofzumahaus, A., Huntrieser, H., Isaksen, I. S. A., Jenkin, M. E., Kaiser, J., Kanakidou, M., Klimont, Z., Kulmala, M., Laj, P., Lawrence, M. G., Lee, J. D., Liousse, C., Maione, M., McFiggans, G., Metzger, A., Mieville, A., Moussiopoulos, N., Orlando, J. J., O’Dowd, C., Palmer, P. I., Parrish, D. D., Petzold, A., Platt, U., Poeschl, U., Prevot, A. S. H., Reeves, C. E., Reimann, S., Rudich, Y., Sellegri, K., Steinbrecher, R., Simpson, D., Ten Brink, H., Theloke, J., van der Werf, G. R., Vautard, R., Vestreng, V., Vlachokostas, C., and Vonglasow, R.: Atmospheric composition change - global and regional air quality, Atmos. Environ., 43, 5268-5350, 2009.

Petters, M. D. and Kreidenweis, S. M.: A single parameter representation of hygroscopic growth and cloud condensation nucleus activity, Atmos. Chem. Phys., 7, 1961-1971, doi:10.5194/acp-71961-2007, 2007.

Pilinis, C., Pandis, S. N., and Seinfeld, J. H.: Sensitivity of direct climate forcing by atmospheric aerosols to aerosol size and composition, J. Geophys. Res., 100, 18739-18754, 1995.

Rudich, Y., Donahue, N. M., and Mentel, T. F.: Aging of organic aerosol: Bridging the gap between laboratory and field studies, Ann. Rev. Phys. Chem., 58, 321-352, 2007.

Schuh, G., Heiden, A. C., Hoffmann, T., Kahl, J., Rockel, P., Rudolph, J., and Wildt, J.: Emissions of volatile organic compounds from Sunflower and Beech: Dependence on temperature and light intensity, J. Atmos. Chem., 27, 291-318, 1997.

Seufert, G., Bartzis, J., Bomboi, T., Ciccioli, P., Cieslik, S., Dlugi, R., Foster, P., Hewitt, C. N., Kesselmeier, J., Kotzias, D., Lenz, R., Manes, F., Pastor, R. P., Steinbrecher, R., Torres, L., Valentini, R., and Versino, B.: An overview of the Castelporziano experiments, Atmos. Environ., 31, Suppl. 1, 5-17, 1997.

Shao, M., Czapiewski, K. V., Heiden, A. C., Kobel, K., Komenda, M., Koppman, R., and Wildt, J.: Volatile organic compound emissions from Scots pine: Mechanisms and description by algorithms, J. Geophys. Res., 106, 20483-20491, 2001.
Sitch, S., Cox, P. M., Collins, W. J., and Huntingford, C.: Indirect radiative forcing of climate change through ozone effects on the land-carbon sink, Nature, 448, 791-794, 2007.

Solomon, S., Qin, D., Manning, M., Alley, R. B., Berntsen, T., Bindoff, N. L., Chen, Z., Chidthaisong, A., Gregory, J. M., Hegerl, G. C., Heimann, M., Hewitson, B., Hoskins, B. J., Joos, F., Jouzel, J., Kattsov, V., Lohmann, U., Matsuno, T., Molina, M., Nicholls, N., and Overpeck, J., Raga, G., Ramaswamy, V., Ren, J., Rusticucci, M., Somerville, R., Stocker, T. F., Whetton, P., Wood, R. A., and Wratt, D.: Technical Summary, in: Climate Change 2007: The Physical Science Basis. Contribution of Working Group I to the Fourth Assessment Report of the Intergovernmental Panel on Climate Change, Cambridge, 2007.

Spindler, C., Abo Riziq, A., and Rudich, Y.: Retrieval of aerosol complex refractive index by combining cavity ring down aerosol spectrometer measurement with full size distribution information, Aerosol Sci. Tech., 41, 1011-1017, 2007.

Staudt, M. and Seufert, G.: Light-dependent emission of monoterpenes by Holm Oak (Quercus ilex L.), Naturwissenschaften, 82, 89-92, 1995.

Staudt, M. and Bertin, N.: Light and temperature dependence of the emission of cyclic and acyclic monoterpenes from Holm Oak (Quercus ilex L.) leaves, Plant Cell Environ., 21, 385-395, 1998.

Staudt, M., Rambal, S., Joffre, R., and Kesselmeier, J.: Impact of drought on seasonal monoterpene emissions from Quercus ilex in southern France, J. Geophys. Res., 107, 4602, doi:10.1029/2001JD002043, 2002.

Staudt, M., Seufert, G., Kotzias, D., Sparta, C., and Ciccioli, P.: Holm Oak (Quercus ilex) - a strong emitter of monoterpenes, in: Proceedings of the 1 st Italian Symposium on the strategies and techniques for the monitoring of the atmosphere, edited by: Ciccioli, P., Societa Chimica Italiana, Rome, 579-586, 1993.

Twomey, S.: The influence of pollution on the shortwave albedo of clouds, J. Atmos. Sci., 34, 1149-1152, 1977.

VanReken, T. M., Greenberg, J. P., Harley, P. C., Guenther, A. B., and Smith, J. N.: Direct measurement of particle formation and growth from the oxidation of biogenic emissions, Atmos. Chem. Phys., 6, 4403-4413, doi:10.5194/acp-6-4403-2006, 2006. 